\title{
Macronutrient and amino acids composition of milk replacers for dairy calves
}

\author{
Composição em macronutrientes e aminoácidos de sucedâneos lácteos para bezerros \\ leiteiros
}

\author{
BITTAR, Carla Maris Machado ${ }^{1 *}$; SILVA, Jackeline Thais da ${ }^{1}$; CHESTER-JONES, \\ Hugh $^{2}$
}

\footnotetext{
${ }^{1}$ University de São Paulo, Escola Superior de Agricultura Luiz de Queiroz, Departamento de Zootecnia, Piracicaba, São Paulo, Brasil.

${ }^{2}$ University of Minnesota, Department of Animal Science, Minneapolis, United States of America.

*Endereço para correspondência: carlabittar@usp.br
}

\section{SUMMARY}

Other than crude protein $(\mathrm{CP})$, crude energy (CE) and crude fiber (CF) content, the adequate supply of essential amino acids (EAA) is an important factor in milk replacer evaluation. The aim of this study was to analyze milk replacer samples as regard to nutrients, especially EAA, composition and simulate the attainability of calves' requirements in different feeding systems. Forty-one milk replacer samples were collected from 14 brands and analyzed for nutrient composition. The near infrared spectroscopy technique was used for AA content estimation. Samples presented adequate levels of CP $(21.2 \pm 2.90 \%)$ and ether extract $(14.5 \pm 3.41 \%)$ for calves fed according to the conventional $(4 \mathrm{~L} / \mathrm{d})$, but not for intensive milk feeding system $(>6 \mathrm{~L} / \mathrm{d})$. High values of CF were observed in the samples $(1.6 \pm 0.86 \%)$. The EAA composition of milk replacer samples was lower than expected for a liquid feed supposed to replace whole milk. None of the analyzed samples presented adequate lysine $(5.72 \pm 1.09 \%$ $\mathrm{CP})$ or methionine $(1.65 \pm 0.38 \% \mathrm{CP})$ to meet calves' daily requirements, regardless of feeding system. Higher crude protein milk replacers are needed. Alternatively, supplementation of milk replacers with EAA is recommended.

Keywords: calves, lysine, methionine, weaning

\section{RESUMO}

Além da proteína bruta $(\mathrm{PB})$, gordura $(\mathrm{EE}) \mathrm{e}$ teor de fibra bruta (FB), o suprimento adequado de aminoácidos essenciais (AAE) é um fator importante na avaliação de sucedâneos lácteos. O objetivo deste estudo foi analisar amostras de sucedâneos lácteos quanto a sua composição em nutrientes e simular o atendimento das exigências de AEE de bezerros em diferentes sistemas de aleitamento. Quarenta e uma amostras de sucedâneos foram coletadas de 14 marcas e analisadas quanto à composição em nutrientes. A técnica de espectroscopia de infravermelho próximo foi utilizada para estimativa de conteúdo de AAE. As amostras apresentaram níveis adequados de PB (21,2 \pm $2,90 \%)$ e $\operatorname{EE~}(14,5 \pm 3,41 \%)$ para bezerros aleitados de acordo com o sistema de alimentação convencional (4L/d), mas não para sistema intensivo $(>6 \mathrm{~L} / \mathrm{d})$. Foram observados valores elevados de $\mathrm{FB}(1,6 \pm 0,86 \%)$. A composição em EAA dos sucedâneos foi menor que o esperado para dieta líquida que substitui o leite integral. Nenhuma das amostras analisadas apresentou concentração adequada de lisina $(5,72 \pm 1,09 \% \mathrm{~PB})$ ou metionina $(1,65 \pm 0,38 \%$ PB) para atender as exigências diárias dos bezerros, independentemente do sistema de aleitamento. É clara a necessidade de sucedâneos com maior teor de PB. Alternativamente, recomenda-se a suplementação de sucedâneos lácteos com AAE.

Palavras-chave: bezerros, desaleitamento, lisina, metionina 


\section{INTRODUCTION}

During the last decades MR composition were improved aiming increased performance and price reduction. Because whey is a very expensive protein source with an increasing demand for human (MORRISON et al., 2017), several ingredients are utilized to replace protein from milk sources, normally trough vegetable ingredients. However, this type of substitution may decrease MR quality, decreasing performance and increasing morbidity (TOMKINS \& JASTER, 1991). The two most used ingredients to replace milk sources of protein are the soluble wheat gluten protein (SWG) and concentrated soy protein (CS) (DRACKLEY et al., 2006). The CS is limited in methionine (Met) and lysine (Lys) (DAWSON et al., 1988) and the SWG is limited in Lys and other EAA (TERUI et al., 1996).

The last NRC publication (NRC, 2001) used a factorial method to calculate the apparent digestible protein (ADPR) requirement of young calves and included a model to predict protein- and energy-limited ADG of calves. However, there is not yet a model that accomplish the AA requirements for calves. Nevertheless, several studies have been conducted to established AA needs according to the growth rate (GERRITS at al., 1997; Hill et al., 2008; Hill et al., 2009; Hill et al., 2013). The base to formulate a MR is the whole milk composition, since it is the ideal feed for calves, with adequate AA profile and high biological value (DRACKLEY et al., 2006). However, MR may hardly mimic those attributes of milk. Recommendations made by Hill et al. (2008) for daily feeding of 17 $\mathrm{g}$ of Lys and $5.4 \mathrm{~g}$ of Met for calves under the age of five weeks, has been proven to be adequate to supply AA requirements and assure adequate growth rates.

In more developed dairy systems there are well established rules for the use of MR (BAMN, 2014). In Brazil, even though some products may be used in different feeding situations, there are not enough information or producer training to adopt this technology. Most producers feed calves according to the conventional feeding system $(4 \mathrm{~L} / \mathrm{d})$, however some have been increasing volume fed (SANTOS \& BITTAR, 2015), seeking higher rates of gain and improved future lactation performance (SOBERON et al., 2012).

The objective of this study was to evaluate the nutrient composition of MR, with special attention to the EAA content, mainly Lys and Met. Other than that, verify the need of MR supplementation with synthetic AA, to meet daily requirements of dairy calves.

\section{MATERIAL AND METHODS}

To avoid company's interference, MR samples of different brands were collected or received directly from farms, all from the south and southeast of Brazil. Forty-one (41) samples of fourteen (14) different brands were collected or received from producers in plastic bags, which were stored in the refrigerator for latter analysis. Milk replacer's samples were analyzed for dry matter (DM), ashes, and crude fiber (CF) according to the Association of Official Analytical Chemists - AOAC (2000). Nitrogen was determined by combustion, according to the Dumas method (AOAC, 2000), using an $\mathrm{N}$ analyzer by LECO, model FP-528 (St. Joseph, MI, USA) and CP was calculated by multiplying the results by 
6.25. Ether extract was analyzed according to AOAC (2000), however acidifying the solvent (90 petroleum ether: 10 acetic acid) to allow complete fat extraction. Crude energy was determined by a calorimetric bomb PARR 1261 (Parr Instrument Company, Moline, Illinois, EUA) with approximately $1 \mathrm{~g}$ of MR sample. All samples were analyzed in triplicates and a simple mean was calculated only when replicates were within 5\% difference.

The near infrared reflectance spectroscopy (NIRS) was utilized to predict the EAA content of milk replacer samples. Using a FOSS 5000 NIRSystem (Foss NIR Systems Inc., Silver Spring, MD, USA), at the Animal Science Department/College of Agriculture/University of Sao Paulo, samples spectra were measured in the wavelength range from 1,100 to 2,498 $\mathrm{nm}$, using a quarter cup cell, and stored as $\log (1 / \mathrm{R})$, where $\mathrm{R}=$ reflectance. Since the equipment from the University of Sao Paulo is standardized with the one from Adisseo Brasil Nutrição Animal Ltda., samples spectra were electronically sent to the company and estimations were done with a validated calibration curve for milk products. Adisseo's calibration curve was developed according to Shenk \& Westerhaus (1991), by the software WINISI 1.5 (Infrasoft International, Silver Spring, MD, USA), with data from samples subjected to EAA determination by high performance liquid chromatography.

Data was summarized by simple descriptive statistics, since comparison of different brands was not the objective of this study. Essential amino acid content data was utilized to simulate the amount consumed by day per calf in different feeding systems and verify the attainability of the amino acids requirements according to the literature recommendations (HILL et al., 2008).

\section{RESULTS AND DISCUSSION}

Most of the MR samples presented adequate composition to meet dairy calves' requirements of $\mathrm{CP}$ (18 to $22 \%$ ) and $\mathrm{EE}(10$ to $15 \%)$ for the conventional feeding system $(4 \mathrm{~L} / \mathrm{d})$, according to NRC (2001) with the exception for brand A (Table 1). Crude energy concentrations in the sampled MR, when converted to metabolizable energy, are adequate for maintenance and growth of calves (Table 1). However, crude fiber content in the MR samples were higher than the actual industry recommendation (1.6 vs 0.15 $0.5 \%$ ).

Most of the time, protein and energy contents are used parameters to choose among MR according to the liquidfeeding program. According to Davis \& Drackley (1998), milk replacers should have crude protein between 18 and $24 \%$ of to assure adequate growth for dairy calves fed according to the conventional liquid feeding program (4 L/d). However, in more recent years, the increased volume fed for calves, justified by the higher rates of growth and benefits for future milk production (SOBERON et al., 2012), set the CP and $\mathrm{EE}$ needs to a minimum of 22 and $20 \%$, respectively (BAMN, 2014). Yet, in systems with even higher feeding rates, CP content higher than $25 \%$ may be needed for adequate composition of the gain, with no adjustments needed for the EE content (KERTZ \& LOFTEN, 2013). According to the composition of the analyzed MR, none could be used in intensive liquid feeding systems. Even though brand $\mathrm{N}$ presentded almost $25 \%$ of $\mathrm{CP}$, it is 
inadequate in EE content. However, Santos \& Bittar (2015) showed that several producers move from feeding 4 $\mathrm{L} / \mathrm{d}$ to $6 \mathrm{~L} / \mathrm{d}$ in an attempt to increase daily gains and weight at weaning. Some producers have even gone further, feeding 8 or $10 \mathrm{~L} / \mathrm{d}$, yet without any concern about the increased need of $\mathrm{CP}$ content to meet requirements of calves under higher growth rates, without negatively affect the composition of the gain. De Paula et al. (2017) have shown that the intensive liquid feeding with a medium CP liquid diet does not improve gain, as compared to de conventional feeding system, because of the higher concentrate intake when calves are fed smaller volumes of MR.

Table 1. Chemical analysis of milk replacers commercialized in Brazil ${ }^{1}$

\begin{tabular}{|c|c|c|c|c|c|c|c|}
\hline \multirow{2}{*}{ Brand } & \multirow{2}{*}{$\mathrm{n}^{2}$} & \multirow{2}{*}{ DM, \% } & Ashes & $\mathrm{CP}$ & $\mathrm{EE}$ & $\mathrm{CF}$ & \multirow{2}{*}{$\begin{array}{c}\mathrm{CE}, \\
\mathrm{cal} / \mathrm{g} \mathrm{DM}\end{array}$} \\
\hline & & & \multicolumn{4}{|c|}{$\% \mathrm{DM}$} & \\
\hline $\mathrm{A}$ & 1 & $90.66 \pm 0.10$ & $2.66 \pm 0.03$ & $12.48 \pm 0.11$ & $4.91 \pm 0.08$ & $1.91 \pm 0.34$ & $3,935.05$ \\
\hline B & 2 & $94.19 \pm 0.18$ & $7.62 \pm 0.53$ & $19.89 \pm 0.22$ & $15.78 \pm 1.17$ & $0.61 \pm 0.04$ & $4,408.79$ \\
\hline $\mathrm{C}$ & 1 & $94.14 \pm 0.01$ & $4.78 \pm 0.27$ & $20.32 \pm 0.01$ & $11.55 \pm 0.34$ & $2.61 \pm 0.06$ & $4,371.71$ \\
\hline $\mathrm{D}$ & 2 & $94.88 \pm 0.06$ & $7.32 \pm 0.16$ & $20.59 \pm 0.09$ & $11.97 \pm 0.28$ & $1.86 \pm 0.2$ & $4,244.80$ \\
\hline $\mathrm{E}$ & 1 & $95.09 \pm 0.13$ & $5.99 \pm 0.10$ & $20.87 \pm 0.26$ & $14.79 \pm 0.16$ & $1.45 \pm 0.07$ & $4,465.63$ \\
\hline $\mathrm{F}$ & 14 & $95.74 \pm 1.40$ & $9.32 \pm 0.46$ & $20.91 \pm 0.87$ & $15.14 \pm 0.50$ & $1.34 \pm 0.62$ & $4,360.12$ \\
\hline G & 3 & $95.54 \pm 0.21$ & $8.70 \pm 0.17$ & $21.64 \pm 0.38$ & $15.52 \pm 0.38$ & $1.05 \pm 0.04$ & $4,380.41$ \\
\hline $\mathrm{H}$ & 1 & $94.16 \pm 0.07$ & $9.69 \pm 0.50$ & $21.67 \pm 0.34$ & $17.51 \pm 0.54$ & $0.87 \pm 0.18$ & $4,466.00$ \\
\hline I & 2 & $96.49 \pm 0.12$ & $7.50 \pm 0.17$ & $21.69 \pm 0.28$ & $17.13 \pm 0.53$ & - & $4,629.29$ \\
\hline $\mathrm{J}$ & 2 & $95.80 \pm 0.11$ & $6.26 \pm 0.15$ & $22.07 \pm 0.36$ & $15.89 \pm 0.05$ & $1.26 \pm 0.02$ & $6,728.17$ \\
\hline K & 7 & $95.35 \pm 0.44$ & $9.65 \pm 0.11$ & $22.80 \pm 0.36$ & $16.80 \pm 0.41$ & $0.75 \pm 0.29$ & $4,422.43$ \\
\hline $\mathrm{L}$ & 1 & $91.89 \pm 0.08$ & $7.80 \pm 0.08$ & $23.53 \pm 0.26$ & $13.34 \pm 0.39$ & $3.43 \pm 0.04$ & $4,301.57$ \\
\hline M & 3 & $93.13 \pm 0.28$ & $9.38 \pm 0.18$ & $23.86 \pm 0.18$ & $18.53 \pm 0.73$ & $0.87 \pm 0.07$ & $4,576.67$ \\
\hline $\mathrm{N}$ & 1 & $94.22 \pm 0.14$ & $5.22 \pm 0.18$ & $24.94 \pm 0.22$ & $13.87 \pm 0.24$ & $2.65 \pm 0.11$ & $5,399.36$ \\
\hline Mean & & $94.4 \pm 1.59$ & $7.3 \pm 2.09$ & $21.2 \pm 2.90$ & $14.5 \pm 3.41$ & $1.6 \pm 0.86$ & $4,568.87 \pm 68.90$ \\
\hline
\end{tabular}

${ }^{1}$ Brands ordered from the lowest to the highest CP and EE content.

${ }^{2}$ Number of samples used for chemical analysis according to production batch.

Not only the protein amount, but also the quality of the protein source matters for the calf nutrition. According to the processing technology of the soy protein, its inclusion as a replacement for milk protein may reduce dairy calves' daily gain. The soy true protein does not clot in the abomasum, is poorly digested by the young calf (DAVIS \& DRACKLEY, 1998; NRC, 2001), and may lead to the development of allergies in the gastrointestinal tract of the animal, factors that might contribute to the reduction of AA absorption (OTTERBY \& LINN, 1981; ERICKSON et al., 1989; KANJANAPRUTHIPONG, 1998).
Because of that, only older calves $(\approx 21$ days) may be fed liquid diet formula with non-lacteal protein source (NRC, 2001) or vegetable sources without adequate processing as to increase its utilization. However, Raeth et al. (2016) have shown that partial replacement of milk protein for alternative protein sources (wheat gluten, soy protein concentrate, spray dried animal plasma and plant peptide powder) in MR formula may decrease ADG during preweaning phase, but still results in adequate performance, with calves doubling their birth weight by weaning. 
The ether extract and crude protein content of the MR sampled are below those observed in MR commercialized in countries with a more developed dairy industry (Table 1). According to Swank et al. (2013), feeding MR with $\mathrm{CP}$ and EE content lower than $20 \%$, as most of the products sampled in this study, may negatively affect dairy calves' performance. Similarly, Bascom et al. (2007) showed that weight gain and feed efficiency are lower for calves fed with milk replacer with $\mathrm{CP}$ and $\mathrm{EE}$ of $20 \%$, as compared to animals fed whole milk or replacer with higher $\mathrm{CP}$ associated with EE lower than $20 \%$. Studies with MR composed of higher levels of nutrients than those observed in the present study are commonly found in the literature, resulting in higher animal performance (HILL et al., 2008; HILL et al., 2009; LEE et al., 2009) than that reported by Brazilian studies (SILVA et al., 2011; SILVA et al., 2012; SILPER et al., 2014; De Paula et al., 2017). On the other hand, it is important to point out that the total diet crude protein content depends on the quality and the volume of the MR fed, the concentrate starter quality and nutrient composition, the concentrate and MR energy, and finally the protein source fed (DAVIS \& DRACKLEY, 1998).

One of the reasons for the lower inclusion of ether extract is the higher temperatures in Brazil. The thermoneutral zone of neonatal calves varies from 15 to $25^{\circ} \mathrm{C}$, being temperatures below $15^{\circ} \mathrm{C}$ considered as critical, when energy animal needs are increased (STULL \& REYNOLDS, 2008). For older calves, the critical temperature varies between -5 a $-15^{\circ} \mathrm{C}$, which are rarely observed in Brazil. However, even considering the national average temperature, MR could present higher levels of EE, approximately $18 \%$, to increase animal's performance with no negative intake effect, as observed by SILVA et al. (2012). On the other hand, the higher the inclusion of EE in the MR, the lower will be the concentrate intake during the liquid-feeding period (DAVIS \& DRACKLEY, 1998), which is the most important factor for the weaning process. Diets with high EE and adequate protein result in higher efficiency because of the composition of the gain (VAN AMBURGH \& DRACKLEY, 2007).

Crude energy has small nutrition importance for the animal, since it does not represents the readily available energy for maintenance and growth. However, when evaluating whole milk or MR as animal feed, crude energy may be helpful. According to Kertz \& Loften (2013), the nutrients that contribute to energy in these liquid diets (fat, lactose and protein), are highly digestible. Therefore, it is important to consider not only the crude energy content, but also the ingredients utilized in the MR formula. In the milk replacers sampled, values of crude energy (Table 1), when converted to metabolizable energy, are adequate for maintenance and growth of calves. However, energy needs depends on the calf's weight and rate of gain.

The crude fiber content may also affect MR utilization, being always a marker for the inclusion of vegetable sources of nutrients. Crude fiber content in the MR samples were higher than the actual industry recommendation of $0.15 \%$ (BAMN, 2014) or the more conservative recommendation of de $0.5 \%$ (NRC, 2001), suggesting the inclusion of non-lacteal sources. However, vegetable protein highly purified and processed as the isolated soy protein, present low crude fiber. Consequently, a MR containing this source of vegetable protein will reveal 
low level of crude fiber. Even though the soy protein is globally utilized as a replacement for milk protein in MR formula, growth and feed efficiency are lower when this liquid diet is fed, as compared to MR containing milk protein (DRACKLEY, 2006). On the other hand, Ghorbani et al. (2007) report that the inclusion up to $50 \%$ of soy protein in the diet may maintain calf's health up to 4 weeks of age and is economically interesting. Therefore, crude fiber is a MR quality indicator only when the type of vegetable source is poorly utilized by the calf.

As expected, the EAA content in the sampled MR were lower than that observed in the whole milk (Table 2).

Table 2. Amino acids composition of milk replacer commercialized in Brazil (\% CP) ${ }^{1}$

\begin{tabular}{cccccccccc}
\hline Brand & Lys & Met & Tre & Val & Ile & Leu & Phe & Hys & Arg \\
\hline Whole milk $^{2}$ & 8.75 & 3.03 & 4.62 & 6.92 & 6.20 & 10.3 & 5.19 & 2.89 & 3.66 \\
\hline A & 9.11 & 2.80 & 5.06 & 6.77 & 6.77 & 9.73 & 6.15 & 3.27 & 5.76 \\
B & 4.93 & 1.30 & 3.82 & 3.67 & 3.96 & 6.58 & 3.48 & 1.49 & 3.13 \\
C & 6.62 & 2.04 & 4.26 & 5.19 & 4.96 & 8.29 & 4.82 & 2.73 & 4.31 \\
D & 5.53 & 1.50 & 3.83 & 4.15 & 4.20 & 7.14 & 3.94 & 1.85 & 3.57 \\
E & 5.44 & 1.34 & 3.83 & 3.92 & 4.02 & 6.87 & 4.52 & 1.94 & 3.83 \\
F & 5.22 & 1.46 & 3.96 & 3.88 & 3.62 & 6.64 & 3.28 & 1.51 & 2.86 \\
G & 5.23 & 1.47 & 3.78 & 3.78 & 3.60 & 6.58 & 3.32 & 1.56 & 2.92 \\
H & 5.30 & 1.52 & 4.00 & 3.91 & 3.78 & 7.00 & 3.30 & 1.48 & 2.95 \\
I & 6.09 & 1.60 & 4.23 & 4.36 & 4.00 & 7.72 & 3.87 & 1.78 & 3.18 \\
J & 5.68 & 1.58 & 3.96 & 4.17 & 3.80 & 7.22 & 3.57 & 1.72 & 2.99 \\
K & 5.27 & 1.40 & 3.97 & 3.88 & 3.61 & 6.78 & 3.12 & 1.36 & 2.66 \\
L & 4.65 & 1.76 & 2.89 & 3.55 & 4.02 & 5.70 & 4.33 & 1.99 & 4.10 \\
M & 5.28 & 1.53 & 3.80 & 3.96 & 3.57 & 6.62 & 3.08 & 1.64 & 2.68 \\
N & 5.78 & 1.74 & 3.93 & 4.51 & 4.36 & 7.41 & 4.47 & 2.33 & 3,82 \\
\hline Mean & 5.72 & 1.65 & 3.95 & 4.26 & 4.16 & 7.16 & 3.95 & 1.90 & 3.48 \\
SD $( \pm)$ & 1.09 & 0.38 & 0.45 & 0.83 & 0.84 & 0.95 & 0.85 & 0.54 & 0.84 \\
\hline
\end{tabular}

${ }^{1}$ Brands ordered from the lowest to the highest $\mathrm{CP}$ and EE content.

${ }^{2}$ Whole milk AA as \% of true protein content according to Lapierre et al. (2012).

Among the MR nutrients, the EAA present great importance since it may limit growth. The young calf depends on the liquid diet as the main source of nutrients. When the calf starts to consume concentrate and the rumen initiate its development, calves may reduce its dependence from the liquid diet as the only source of protein and start to count on the microbial protein resulting from rumen fermentation. Thereby, the content of EAA in the milk replacer should meet the needs of the calf according to the volume fed, being Lys and Met the most limiting AA for ruminant animal's growth (TZENG \& DAVIS, 1980; HILL et al., 2007; HILL et al., 2008). The EAA content in the MR sampled were lower than that observed in the whole milk (NRC, 2001; LAPIERRE et al., 2012; Table 3). Accordingly, calves fed this type of liquid diet present lower growth when compared to animals fed whole milk (LEE et al., 2009). Whole milk is the liquid diet with the best $\mathrm{AA}$ profile to maximize calves performance (NRC, 2001). According to Hill et al. (2008), an increase of up to $15 \%$ in the weight gain of calves receiving MR formulated 
to meet calves lysine and methionine requirements should be expected. Therefore, MR formulation must consider lysine and methionine content to assure daily intake to meet animal's requirements (HILL et al., 2013). As suggested by Hill et al. (2009), MR with $23 \% \mathrm{CP}$ should present $2.40 \mathrm{~g}$ of lysine and $0.76 \mathrm{~g}$ of methionine $/ 100 \mathrm{~g}$ of MR. These values are approximately twofold of those observed in the analyzed samples of MR (Table 2). In the same manner, Hill et al. (2008) suggest values of $2.39 \mathrm{~g}$ of lysine and $0.75 \mathrm{~g}$ of methionine / $100 \mathrm{~g}$ of MR for higher feed efficiency in MR containing CP from $24 \%$ to $28 \%$. In these studies, not only the diet $\mathrm{CP}$ is considered but also the AA concentration (Lys and Met), as the most important factor for the MR quality.

Simulations comparing feeding volumes of 4 or $6 \mathrm{~L} / \mathrm{d}$ showed that calves do not consume adequate levels of Lys and Met (Table 3). The milk replacer should supply at least $17 \mathrm{~g} / \mathrm{d}$ of lysine and $5.3 \mathrm{~g} / \mathrm{d}$ of methionine for dairy calves (HILL et al., 2008). Simulations show that in none of the feeding systems using the evaluated MR brands, animals would receive daily doses of Lys and Met as proposed by Hill et al. (2008). This AA shortage may be higher depending on the feed management adopted or occur even in systems that feed higher volumes of milk replacer (Table 3 ).

Table 3. Simulation of the daily lysine and methionine intake $(\mathrm{g} / \mathrm{d})$ from milk replacer, according to different volumes fed to dairy calves

\begin{tabular}{|c|c|c|c|c|}
\hline \multirow{3}{*}{ Brand $^{1}$} & \multicolumn{2}{|c|}{ Intake of $4 \mathrm{~L} / \mathrm{d}^{2}$} & \multicolumn{2}{|c|}{ Intake of $6 \mathrm{~L} / \mathrm{d}^{3}$} \\
\hline & Lysine & Methionine & Lysine & Methionine \\
\hline & \multicolumn{4}{|c|}{$\mathrm{g} / \mathrm{d}$} \\
\hline A & 5.68 & 1.75 & 8.53 & 2.62 \\
\hline B & 4.90 & 1.29 & 7.34 & 1.94 \\
\hline $\mathrm{C}$ & 6.73 & 2.07 & 10.09 & 3.10 \\
\hline $\mathrm{D}$ & 5.69 & 1.54 & 8.53 & 2.31 \\
\hline E & 5.68 & 1.39 & 8.52 & 2.09 \\
\hline $\mathrm{F}$ & 5.46 & 1.53 & 8.18 & 2.29 \\
\hline G & 5.66 & 1.59 & 8.49 & 2.40 \\
\hline $\mathrm{H}$ & 5.74 & 1.65 & 8.62 & 2.47 \\
\hline I & 6.61 & 1.73 & 9.91 & 2.60 \\
\hline $\mathrm{J}$ & 6.27 & 1.74 & 9.40 & 2.01 \\
\hline K & 6.00 & 1.60 & 9.00 & 2.40 \\
\hline $\mathrm{L}$ & 5.47 & 2.07 & 8.20 & 3.10 \\
\hline M & 6.30 & 1.83 & 9.45 & 2.74 \\
\hline $\mathrm{N}$ & 7.21 & 2.17 & 10.8 & 3.26 \\
\hline
\end{tabular}

${ }^{1}$ Brands ordered from the lowest to the highest $\mathrm{CP}$ and $\mathrm{EE}$ content.

${ }^{2} 4 \mathrm{~L} / \mathrm{d}$ of MR corresponds to $500 \mathrm{~g}$ of MR powder (dilution to $12.5 \%$ solids).

${ }^{3} 6 \mathrm{~L} / \mathrm{d}$ of MR corresponds to $750 \mathrm{~g}$ of MR powder (dilution to $12.5 \%$ solids).

In conventional feeding systems $(4 \mathrm{~L} / \mathrm{d})$, intake would be approximately half of the daily requirement, which certainly reduce animal performance. Even with the feeding of $6 \mathrm{~L} / \mathrm{d}$, animal's requirements are not met with the milk replacers' amino acid concentration. This result highlights the importance of considering not only the $\mathrm{CP}$, but also the AA content when formulating a 
milk replacer. According to the NRC (2001), the ability of the protein to provide adequate amounts and profile of EAA for pre-ruminant dairy calves growth resides on the protein amino acids profile, the MR processing quality, and the protein digestibility. High temperatures during drying processing may negatively affect the liquid diet quality, resulting in lower protein biological value.

Studies supplementing Lys and Met in milk replacers show performance improvements, with calves growing at higher rates as compared with those fed whole milk. In those studies, the crude protein content of the MR fed was 20\% (HILL et al., 2007; HILL et al., 2013), values similar to those in the analyzed MR samples. These data suggest that adding EAA to these MR may result in a liquid diet without amino acids limitation for dairy calves. The amino acid supplementation may be easily done with the addition of synthetic amino acids. Therefore, to guarantee that animals receive a liquid diet with equivalent quantities of amino acids as in whole milk, all brands analyzed should be supplemented.

Milk replacers present adequate values of crude protein and energy for feeding dairy calves according to the conventional feeding, but not for the intensive feeding system. However, none of the brands analyzed have adequate AA content, mainly lysine and methionine, to meet dairy calves' requirement when fed according to the most used feeding system adopted in Brazil. Therefore, the need of higher CP milk replacers is clear. Alternatively, the supplementation of MR with lysine and methionine amino acids is suggested.

\section{REFERENCES}

\author{
ASSOCIATION of OFFICIAL \\ ANALYTICAL CHEMISTS - AOAC. \\ Official Methods of Analysis. $17^{\text {th }} \mathrm{ed}$. \\ Arlington, VA: AOAC International, \\ 2000.
}

BAMN. A guide to calf milk replacers: types, use, and quality. 2014. $<$ http://www.afia.org/Afia/EducationMat erials/NoChargeDocs.aspx >. Accessed: may $8^{\text {th }} .2014$.

BASCOM, S.A.; JAMES, R.E.; MCGILLIARD, M.L.; van AMBURGH, $M$. Influence of dietary and protein on body composition of Jersey bull calves. Journal of Dairy Science, v.90, n.12, p.5600-5609, 2007.

DAVIS, C.L.; DRACKLEY, J.K. The development, nutrition and management of the young calf. Ames: Iowa State University Press, 1998.

DAWSON, D.P.; MORRILL, J.L.; REDDY, P.G.; MINOCHA, H.C.; RAMSEY, H.A. Soy protein concentrate and heated soy flours as protein sources in milk replacer for preruminant calves.

Journal of Dairy Science, v.71, n.5, p.1301-1309, 1988.

DE PAULA, M.R.; OLTRAMARI, C.E.; SILVA, J.T.; GALLO, M.P.C.; MOURÃO, G.B.; BITTAR, C.M.M. Intensive liquid feeding of dairy calves with a medium crude protein milk replacer: effects on performance, rumen, and blood parameters. Journal of Dairy Science, v.100, n.6, p.4448-4456, 2017. 
DRACKLEY, J.K.; BLOME, R.M.; BARTLETT, K.S.; BAILEY, K.L.

Supplementation of $1 \%$ L-glutamine to milk replacer does not overcome the growth depression in calves caused by soy protein concentrate. Journal of Dairy Science, v.89, n.5, p.1688-1693, 2006.

ERICKSON, P.S.; SCHAUFF, D.J.; MURPHY, M.R. Diet digestibility and growth of Holstein calves fed acidified milk replacers containing soy protein concentrate. Journal of Dairy Science, n.72, v.6, n.1528-1533, 1989.

GERRITS, W.J.J.; FRANCE, J.; DIJKSTRA, J.; BOSCH, M.W.; TOLMAN, G.H.; TAMMINGA, S. Evaluation of a model integrating protein and energy metabolism in preruminant calves. Journal of Nutrition, v.127, n.6, p.1243-1252, 1997.

GHORBANI, G.R.; KOWSAR, R.; ALIKHANI, M.; NIKKHAH, A. Soymilk as a novel milk replacer to stimulate early calf and reduce weaning age and costs. Journal of Dairy Science, v.90, n.12, p.5692-5697, 2007.

HILL, T.M.; BATEMAN II, H.G.; QUIGLEY III, J.D.; ALDRICH, J.M.; SCHLOTTERBECK, R.L.;

HEINRICHS, A.J. Review: New information on the protein requirements and diet formulation for dairy calves and heifers since the Dairy NRC 2001.

Professional Animal Scientist, v.29, n.3, p.199-207, 2013.

HILL, T.M.; BATEMAN II, H.G.; ALDRICH, J.M.; SCHLOTTERBECK, R.L. Effect of weaning age of dairy calves fed a conventional or more optimum milk replacer program.

Professional Animal Scientist, v.25, n.5, p.619-624, 2009.
HILL, T.M.; BATEMAN II, H.G.; ALDRICH, J.M.; SCHLOTTERBECK, R.L.; TANAN, K.G. Optimal concentrations of lysine, methionine, and threonine in milk replacers for calves less than five weeks of age. Journal of Dairy Science, v.91, n.6, p.2433-2442, 2008.

HILL, T.M.; ALDRICH, J.M.; SCHLOTTERBECK, R.L.; BATEMAN II, H.G. Amino acids, fatty acids, and fat sources for calf milk replacers.

Professional Animal Scientist, v.23, n.4, p.401-408, 2007.

KANJANAPRUTHIPONG, J.

Supplementation of milk replacers containing soy protein with threonine, methionine, and lysine in the diets of calves. Journal of Dairy Science, v.81, n.11, p.2912-2915, 1998.

KERTZ, A.F.; LOFTEN, J.R. A historical perspective of specific milkreplacer feeding programs in the United States and effects on eventual performance of Holstein dairy calves. Professional Animal Scientist, v.29, n.4, p.321-332, 2013.

\section{LAPIERRE, H.; LOBLEY, G.E.;} DOEPEL, L.; RAGGIO, G.; RULQUIN, H.; LEMOSQUET, S. Triennial lactation symposium: Mammary metabolism of amino acids in dairy cows. Journal of Animal Science, v.90, n.5, p.1708-1721, 2012.

LEE, H.J.; KHAN, M.A.; LEE, W.S.; YANG, S.H.; KIM, S.B.; KI, K.S.; KIM, H.S.; HA, J.K.; CHOI, Y.J. Influence of equalizing the gross composition of milk replacer to that of whole milk on the performance of Holstein calves. Journal of Animal Science, v.87, n.3, p.1129-1137, 2009. 
MORRISON, S.Y.; CAMPBELL, J.M.; DRACKLEY, J.K. Amino acid supplementation of calf milk replacers containing plasma protein. Journal of Dairy Science, v.100, n.6., p.46374649, 2017.

NATIONAL RESEARCH COUNCIL NRC. Nutrient requirements of dairy cattle. $7^{\text {th }}$ ed. rev. Washington, DC: National Academy Press, 2001.

OTTERBY, D.E.; LINN, J.G. Advances in nutrition and management of calves of calves and heifers. Journal of Dairy Science, v.64, n.6, p.1365-1377, 1981.

RAETH, M.; CHESTER-JONES, H.; ZIEGLER, D.; ZIEGLER, B.; SCHIMEK, D.; COOK, D.L.; GOLOMBESKI, G.; GROVE, A.V. Preand post-weaning performance and health of dairy calves fed milk replacers with differing protein sources. Professional Animal Scientist, v.32, n.6, p.833-841, 2016.

SANTOS, G.; BITTAR, C.M.M. A survey of dairy calf management practices in some producing regions in Brazil. Brazilian Journal of Animal Science, v.44, n.10, p.361-370, 2015.

SHENK, J.S.; WESTERHAUS, M.O. Population definition, Sample selection, and calibration procedures for near infrared reflectance spectroscopy. Crop Science, v.31, n.2, p.469-474, 1991.

SILPER, B.F.; LANA, A.M.Q.; CARVALHO, A.U.; FERREIRA, C.S.; FRANZONI, A. P.S.; LIMA, J.A.M.; SATURNINO, H.M.; REIS, R.B.; COELHO, S.G. Effects of milk replacer feeding strategies on performance, ruminal development, and metabolism of dairy calves. Journal of Dairy Science, v.97, n., p.1016-1025, 2014.
SILVA, J.T.; BITTAR, C.M.M.; FERREIRA, L.S. Desempenho e desenvolvimento ruminal em resposta ao fornecimento de substâncias húmicas para bezerros leiteiros em sistema de desaleitamento precoce. Acta Scientiarum Animal Science, v.33, n.4, p.395-401, 2011.

SILVA, J.T.; BITTAR, C.M.M.; FERREIRA, L.S. Evaluation of mannanoligosaccharides offered in Milk replacers or starters and their effect on performance and rumen development of dairy calves. Brazilian Journal of Animal Science, v.41, n.3, p.748-762, 2012.

SOBERON, F.; RAFFRENATO, E.; EVERETT, R.W.; AMBURGH, M.E. Preweaning milk replacer intake and effects on long-term productivity of dairy calves. Journal of Dairy Science, v.95, n.2, p.783-793, 2012.

STULL, C.; REYNOLDS, J. Calf Welfare. Veterinary Clinics of North America: Food Animal Practice, v.24, n.1, p.191-203, 2008.

SWANK, V.A.; YOKO, W.S.; O`DIAM, K.M.; EASTRIDGE, M.L.; NIEHAUS, A.J. DANIELS, K.M. Jersey calf performance in response to high-protein, high-fat liquid feeds with varied fatty acid profiles: blood metabolites and liver gene expression. Journal of Dairy Science, v.96, n.6, p.3845-3856, 2013.

TERUI, H.; MORRILL, J.L.; HIGGINS, J.J. Evaluation of Wheat Gluten in Milk replacers and Calf Starters. Journal of Dairy Science, v.79, n.7, p.1261-1266, 1996. 
TOMKINS, T.; JASTER, E.H.

Preruminant calf nutrition. Veterinary

Clinics of North America: Food

Animal Practice, v.7, n.2, p.557-576, 1991.

TZENG, D.; DAVIS, C.L. Amino acid nutrition of the young calf: estimation of methionine and lysine requirements.

Journal of Dairy Science, v.63, n.3, p.441-450, 1980.

VAN AMBURGH, M.; DRACKLEY, $\mathrm{J}$. Current perspectives on the energy and protein requirements of the preweaned calf. In: GARNSWORTHY, P.C. Calf and heifer rearing.

Thrumpton: Nottingham University Press, 2007.

Receipt date: $22 / 08 / 2017$

Approval date: 19/02/2018 